\section{Effects of Pyridalyl on ATP Concentrations in Cultured Sf9 Cells}

\author{
Shigeru SAITO* \\ Agricultural Chemicals Research Laboratory, Sumitomo Chemical \\ Co. Ltd., 2-1, Takatsukasa-4, Takarazuka, Hyogo 665-8555, Japan
}

(Received May 18, 2005; Accepted July 22, 2005)

The effects of pyridalyl and various cytotoxic substances on ATP levels in cultured Sf9 cells were compared. Levels decreased markedly after treatment with the mitochondrial respiration disruptors acequinocyl $(10 \mu \mathrm{M})$, chlorfenapyr (1.0-10 $\mu \mathrm{M})$, fenpyroxymate $(0.01-1.0 \mu \mathrm{M})$, rotenone $(0.1-10 \mu \mathrm{M})$, 2-chlorocarbonylcyanide phenylhydrazine $(0.1-1.0 \mu \mathrm{M})$ and oligomycin $(0.1-10 \mu \mathrm{M})$, but increased after treatment with $10 \mu \mathrm{M}$ of anisomycin, a protein synthesis inhibitor. An RNA synthesis inhibitor, 5-fluorouracil $(0.1-10 \mu \mathrm{M})$, did not have any effect. Pyridalyl $(0.1-10 \mu \mathrm{M})$ reduced the ATP content of the cells; however, the rate of the decrease was not rapid. C Pesticide Science Society of Japan

Keywords: pyridalyl, Sf9, cytotoxicity, ATP.

\section{INTRODUCTION}

Previously, pyridalyl, a novel insecticide, was found to be cytotoxic to cultured Sf9 insect cells. ${ }^{1)}$ The effects of pyridalyl and other substances on cultured Sf9 cells were determined by measuring the number of cells at $72 \mathrm{hr}$ after treatment using the trypan blue exclusion method. Although the method was sufficient to determine the number of viable cells at $72 \mathrm{hr}$ after treatment, it was not always sufficient to detect the effects within several hours after treatment. Comparing the reactions of the cells within several hours after treatment with substances would provide us with information about the mechanisms of their effects on the cells.

ATP levels in cells are influenced by various external factors and indicate the condition of the cells. They can be measured quickly with high sensitivity based on the intensity of the bioluminescence generated from the luciferin-luciferase reaction. In the present study, the effects of pyridalyl on the ATP content of Sf9 cells were compared to those of various cytotoxic substances.

\footnotetext{
* Present address: Crop Protection Division-International, Sumitomo Chemical Co. Ltd., 27-1, Shinkawa-2, Chuo-ku, Tokyo 104-8260, Japan E-mail: saitous6@sc.sumitomo-chem.co.jp (C) Pesticide Science Society of Japan
}

\section{MATERIALS AND METHODS}

\section{Chemicals}

A technical sample (97\%) of pyridalyl was provided by the Agricultural Chemicals Research Laboratory (ACRL) of Sumitomo Chemical Co. Ltd. Anisomycin, oligomycin, rotenone and 2chlorocarbonylcyanide phenylhydrazine (CCCP) were purchased from Sigma (St. Louis, MO, USA). 5-Fluorouracil (5-FU) was purchased from Nacalai Tesque, Inc. (Kyoto, Japan). Other chemicals were purchased from Wako Pure Chemical Industries, Ltd. (Osaka, Japan).

\section{Sf9 Cells}

A frozen stock of Sf9 cells derived from pupal ovarian tissue of Spodoptera frugiperda (Smith) was purchased from Invitrogen Corp. (Carlsbad, CA, USA). The cultures were routinely maintained at $27^{\circ} \mathrm{C}$ in $75-\mathrm{cm}^{2}$ culture flasks in $10 \mathrm{ml}$ of EX$\mathrm{CELL}^{\mathrm{TM}} 400$ serum-free medium (JRH Biosciences, Inc., Lenexa, KS, USA) as a monolayer. Cells were sub-cultured every 3-4 days.

\section{Measurement of ATP Levels in Sf9 Cells}

Tests were carried out in opaque-walled 96-well flat bottom microplates with $100 \mu$ l of culture medium per well. The Sf9 cells were dispensed at $1.0 \times 10^{4}$ cells per well, then incubated at $27^{\circ} \mathrm{C}$ for $20-24 \mathrm{hr}$. Since the cells were cultured under confluent conditions before being dispensed, they did not proliferate in the wells. Then, $0.5 \mu \mathrm{l}$ of EtOH solution containing the test compound was added to give the prescribed final concentration in the cells and incubated for the prescribed number of hours. The ATP content in the well was determined using a commercial product, CellTiter-Glo ${ }^{\mathrm{TM}}$ Luminescent Cell Viability Assay Kit (Promega Corporation, Madison, WI, USA) on 1450 MicroBeta TriLux ${ }^{\circledR}$ and MicroBeta JET $^{\circledR}$ (PerkinElmer Life Sciences, Turku, Finland). Each treatment consisted of 6 wells of the microplate. The wells on the edge of the plate were not used. The calibration curve for ATP content was established based on the luminescence intensities of ATP solutions at the prescribed concentration.

\section{RESULTS}

Treatment with acequinocyl $(10 \mu \mathrm{M})$, chlorfenapyr $(1.0-10 \mu \mathrm{M})$, fenpyroxymate $(0.01-1.0 \mu \mathrm{M}), \operatorname{CCCP}(0.1-1.0 \mu \mathrm{M})$, rotenone $(0.1-10 \mu \mathrm{M})$ and oligomycin $(0.1-10 \mu \mathrm{M})$ decreased the concentration of ATP in Sf9 cells by $c a$. $0.2 \mu \mathrm{M} / 10^{4}$ cells or less within $4 \mathrm{hr}$ of treatment. (Fig. 1A-F) While clear dose-dependent responses were observed following treatment with acequinocyl, chlorfenapyr, CCCP or oligomycin, no such responses were found after treatment with fenpyroxymate $(0.01-1.0 \mu \mathrm{M})$ or rotenone $(0.1-10 \mu \mathrm{M})$.

On treatment with pyridalyl at $1.0-10 \mu \mathrm{M}$, ATP levels also decreased with time. (Fig. 1H) While a clear dose-dependent response was observed in the cells treated with pyridalyl, signifi- 

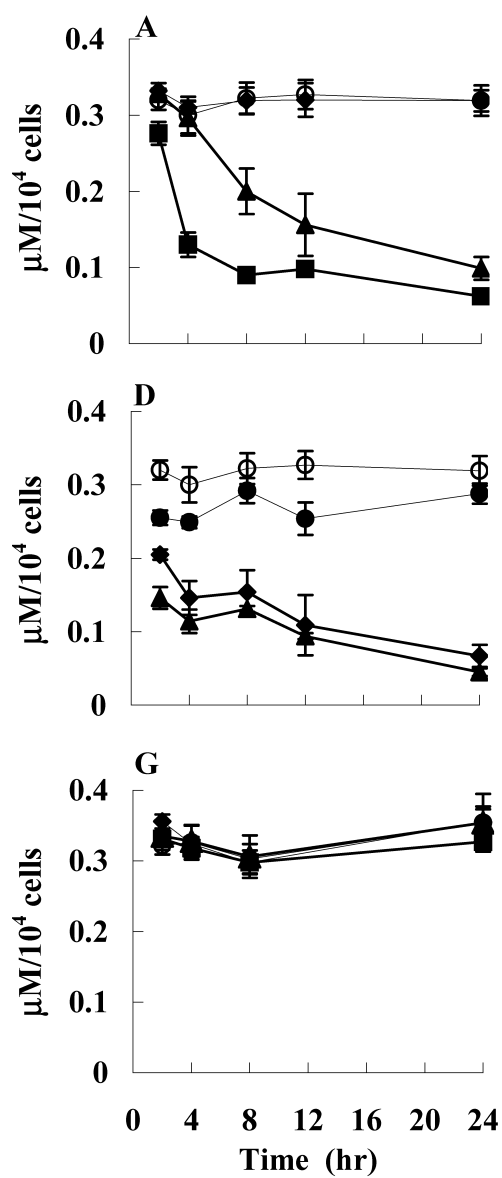
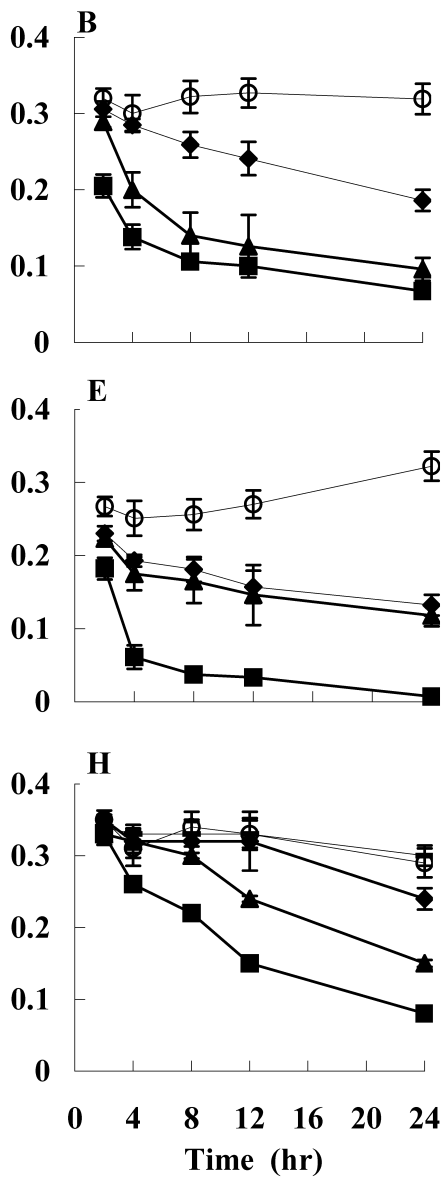
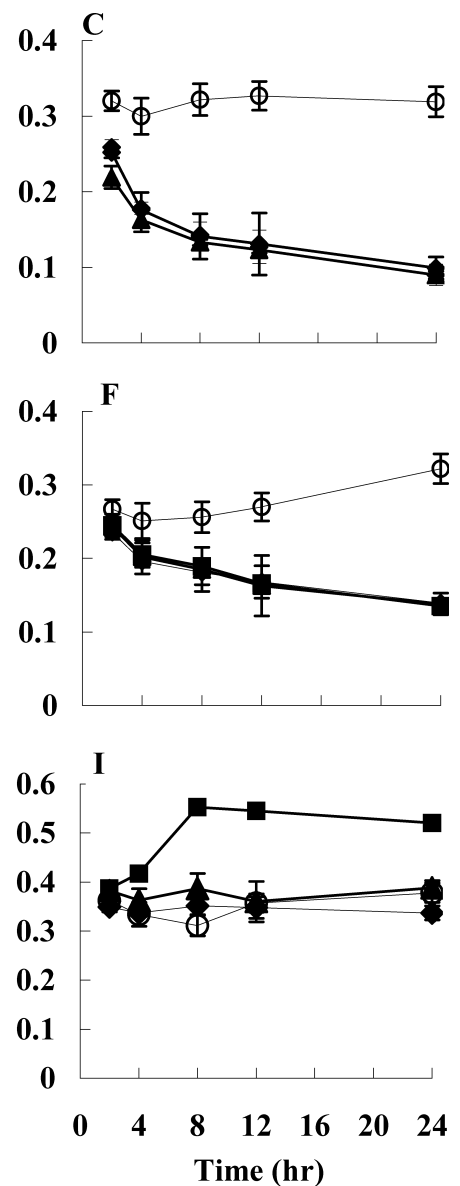

Fig. 1. Effect of acequinocyl (A), chlorfenapyr (B), fenpyroxymate (C), CCCP (D), oligomycin (E), rotenone (F), 5-fluorouracil (G), pyridalyl (H) and anisomycin (I) on ATP concentrations in Sf9 cell cultures.

Each compound was tested at concentrations of $10 \mu \mathrm{M}(\boldsymbol{\square}), 1.0 \mu \mathrm{M}(\boldsymbol{\Delta}), 0.1 \mu \mathrm{M}(\diamond)$ and $0.01 \mu \mathrm{M}(\bullet)$. The ATP levels in the control group are expressed with a blank circle $(\bigcirc)$. Vertical lines represent \pm SD.

cant decreases from control levels on treatment with 10 and $1.0 \mu \mathrm{M}$ appeared after 2 and $8 \mathrm{hr}$, respectively. It took $24 \mathrm{hr}$ to observe a significant decrease in ATP content after treatment with $0.1 \mu \mathrm{M}$. No significant difference was observed between $0.01 \mu \mathrm{M}$ of pyridalyl and the control. The dose responses of the effects on the ATP levels are consistent with dose responses for cytotoxicity in Sf9 cells, where pyridalyl is not toxic to Sf9 cells at concentrations lower than $0.01 \mu \mathrm{M}$.

The treatment with anisomycin $(10 \mu \mathrm{M})$ increased the ATP content of the Sf9 cells $6 \mathrm{hr}$ after treatment and maintained a similar level even $24 \mathrm{hr}$ after treatment. There were no significant changes on treatment with 1.0 and $0.1 \mu \mathrm{M}$. (Fig.1I) 5-FU did not affect ATP levels in the cells, even at $10 \mu \mathrm{M}$. (Fig.1G)

\section{DISCUSSION}

In the present study, it was shown that the ATP levels in Sf9 cells were apparently reduced by treatment with substances disrupting mitochondrial respiration within several hours. Acequinocy,2) fenpyroxymate $^{3)}$ and rotenone are insecticides/acaricides with inhibitory effects on the mitochondrial respiratory chain. Chlorfenapyr $\left.{ }^{4}\right)$ and CCCP are known as uncouplers of oxidative phos- phorylation in mitochondria. Oligomycin is an $\mathrm{F}_{0} \mathrm{~F}_{1}$-ATPase inhibitor. Hence, compounds causing a fast decline in the ATP content of Sf9 cells, such as these compounds, might generally act on mitochondrial respiration directly.

While the cytotoxic effects of 5-FU are also known ${ }^{5,6)}$ and it has been reported that the compound suppressed the proliferation of Sf9 cells, ${ }^{1)}$ no significant effects on ATP levels in Sf9 cells were caused by the compound in the present study. This suggests that the disruption of RNA synthesis does not influence the ATP content of the cells directly.

The effect of $10 \mu \mathrm{M}$ anisomycin on the levels of ATP in Sf9 cells was remarkable. Known as an inhibitor of protein biosynthesis, ${ }^{7)}$ anisomycin was actually shown to be toxic to Sf9 cells in a previous report. ${ }^{1)}$ Further, it was reported that anisomycin induced apoptosis in CF-203 cells, a continuous line of midgut cells of the spruce budworm, Choristoneura fumiferana. ${ }^{8)}$ In addition, an increase in the ATP content of cells undergoing apoptosis induced by anisomycin was reported. ${ }^{9)}$ Taking this into consideration, anisomycin may cause apoptosis of Sf9 cells.

Pyridalyl was previously reported to be toxic to Sf9 cells. ${ }^{1)}$ While the present study also showed that pyridalyl at 1.0 and 
$10 \mu \mathrm{M}$ apparently reduced the viability of Sf9 cells within several hours of treatment, the decline in ATP content was not as rapid as that in the Sf9 cells treated with substances acting on mitochondrial respiration. In contrast, it was shown that pyridalyl did not influence the respiration of mitochondria isolated from Spodoptera litura. ${ }^{1)}$

Thus, the results of the present study do not contradict previous results obtained by the trypan-blue exclusion method. In conclusion, the cytotoxic effect of pyridalyl at $1.0-10 \mu \mathrm{M}$ on Sf9 cells appeared within several hours after treatment and involved neither the direct disruption of mitochondrial energetics nor the mechanism of action of 5-FU or anisomycin. Investigations are on-going.

\section{REFERENCES}

1) S. Saito, N. Sakamoto and K. Umeda: J. Pestic. Sci. 30, 17-21 (2005).
2) Y. Koura, S. Kinoshita, K. Takasuka, S. Koura, N. Osaki, S. Matsumoto and H. Miyoshi: J. Pestic. Sci. 23, 18-21 (1998).

3) K. Motoba, T. Suzuki and M. Uchida: Pestic. Biochem. Physiol. 43, 37-44 (1992).

4) B. C. Black, R. M. Hollingworth, K. I. Ahmmadsahib, C. D. Kukel and S. Donovan: Pestic. Biochem. Physiol. 50, 115-128 (1994).

5) J. G. Cory, J. C. Breland and G. L. Carter: Cancer Res. 39, 4905-4913 (1979).

6) C. P. Spears, B. G. Gustavsson, M. S. Mitchell, D. Spicer, M. Berne, L. Bernstein and P. G. Danenberg: Cancer Res. 44, 4144-4150 (1984).

7) J. Liao, N. Ku and M. B. Omary: J. Biol. Chem. 272, 1756517573 (1997).

8) S. R. Palli, S. S. Sohi, B. J. Cook, A. J. Brownwright and G. F. Caputo: J. Insect Physiol. 42, 1061-1069 (1996).

9) J. F. Lopez-Saez, R. Mingo and A. Gonzalez-Fernandez: Eur. J. Cell Biol. 27, 185-190 (1982). 